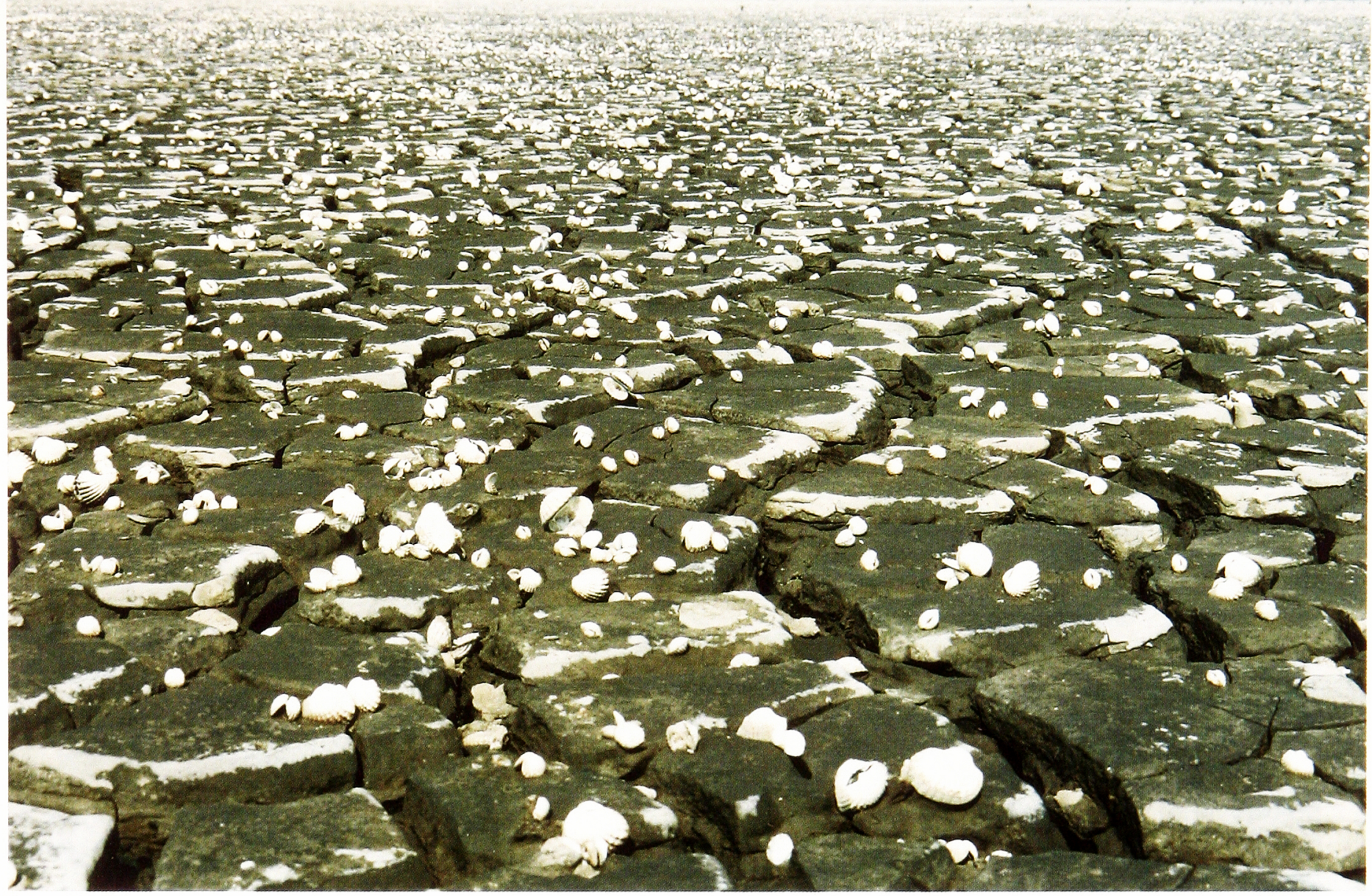

諫早湾干拒地の現世古生態学

佐藤慎一*

\title{
Shin'ichi Sato*: Actuopaleoecology in the tidal flat of Isahaya Bay after reclamation
}

諫早湾奥部では，1997年 4 月 14 日の潮止めにより約 $30 \mathrm{~km}^{2}$ もの 広大な泥質干潟が干上がった．大きな社会問題となった諫早湾干拓 工事だが，現世古生態学的に見ると以下の点で極めて重要な情報を 我々に提供した．1）一般に泥質干潟では底生生物の定量調査が非 常に困難であるが，諫早湾奥部では干潟が干上がることで初めて徒 歩による貝類相の調査が可能となった．2）調整池における潮止め 前後の水質の変化と，それに伴う生物相の変遷を詳細に追跡するこ
とができた.これと類似の現象は，過去の海進・海退に伴う一連の 環境変動の中で何度も生じたであろうと想像できる，従ってこれら の観察事項は，洪積層や沖積層における貝化石群集に基づく古環境 解析に対して, 重要な情報を提供することができると期待される。

\section{文献}

佐藤慎一，1997，諫早湾干拓 貝類の生態. SClaSサイアス，no. 24 , $74-75$.

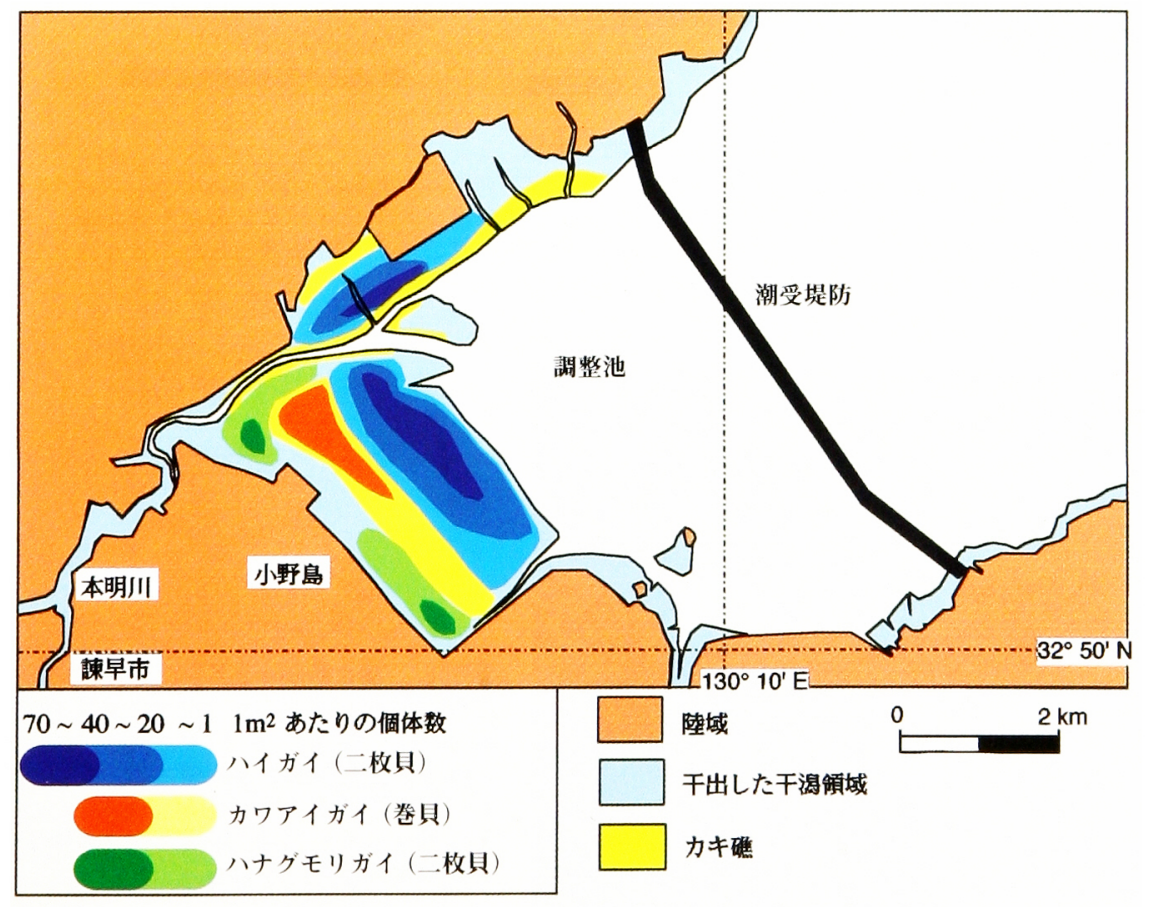

1999 年 9 月 13 日受付。1999年11月 12 日受理. *国立科学博物館地学研究部

Department of Geology, National Science Museum, 3-23-1 Hyakunin-cho, Shinjuku-ku, Tokyo 169-0073, Japan

第1図. 長崎県諫早市の小野島地先 $1 \sim 2 \mathrm{~km}$ に見られ るハイガイTegillarca granosaの密集帯（1997年8月 23 日撮影)。諫早湾奥部の干上がった潮間帯下部には, 夥しい数のハイガイの死殻が転がっていた，ハイガイは 内生種であるが, 周囲の泥の乾燥・収縮により一斉に地 表面に姿を現わした，遠くには建設中（当時）の潮受け 堤防が見える.

第 2 図. 諫早湾奥部における干拓地の位置図および3種 類の貝の分布笎囲（佐藤，1997に一部加筆). 干上がっ た泥質干潟上では，二枚貝・巻貝の各種がそれぞれ海岸 線と平行に密集帯を形成していた。 中でも，ハイガイ, カワアイガイCerithidea djadjariensis, ハナグモリカ 1 Glauconome chinensisの3種は，それぞれ潮間帯下 部, 中部, 上部に特に密集して分布していた. 
